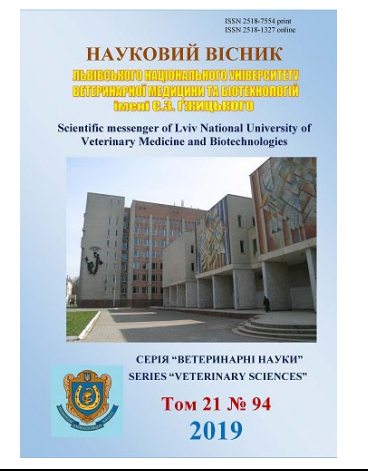

\author{
Науковий вісник Дьвівського національного університету \\ ветеринарної медицини та біотехнологій імені С.3. Гжицького. \\ Серія: Ветеринарні науки
}

Scientific Messenger of Lviv National University

of Veterinary Medicine and Biotechnologies.

Series: Veterinary sciences

ISSN 2518-7554 print

ISSN 2518-1327 online

doi: $10.32718 /$ nvlvet9401

http://nvlvet.com.ua

UDC 619:616.9-036.22

\title{
Pathogenetic aspects of dogs' infectious hepatitis treatment
}

O.Ye. Galatyuk, T.O. Romanyshyna, A.R. Lakhman

Zhytomyr National Agroecological University, Zhytomyr, Ukraine

Article info

Received 18.03.2019

Received in revised form 17.04.2019

Accepted 18.04.2019

Zhytomyr National Agroecological University, Stary Boulevard, 7 , Zhytomyr, 10008, Ukraine. Tel.: +38-097-356-27-07

E-mail:olekhalatyuk@gmail.com, tveterinar@gmail.com, nastyalahman@gmail.com
Galatyuk, O.Ye., Romanyshyna, T.O., \& Lakhman, A.R. (2019). Pathogenetic aspects of dogs' infectious hepatitis treatment. Scientific Messenger of Lviv National University of Veterinary Medicine and Biotechnologies. Series: Veterinary sciences, 21(94), 3-8. doi: 10.32718/nvlvet9401

The article presents the mechanisms of development and dynamics of changes in the treatment of dogs' infectious hepatitis. According to reports from doctors of veterinary medicine in clinics of small animals of Zhytomyr, the following infectious diseases are dominated in dogs: parvovirus enteritis, viral hepatitis, parainfluenic dogs, leptospirosis, carnivorous plague, trichophytosis and food toxicoinfection. One of the most common diseases in clinical practice was infectious hepatitis, which became the object of our research. The study of various aspects of the liver function pathology in diseases of viral etiology is especially relevant because of the exclusive compensatory potentials of this organ, their clinical manifestation is often found in the stage of severe morphofunctional violations, often not subject to reverse development. The purpose of our work was to study the influence Adenovirus canine-a pathogen of dogs' infectious hepatitis, on the functional state of the liver, to find out the effectiveness of the drug hepato-lik in the complex intensive care of sick dogs. The subject of the study were patients with infectious dogs' hepatitis. The main diagnostic criterion was the use of express texts, which confirmed the previous diagnosis - infectious dogs' hepatitis. For the study of the effectiveness of the used treatment of infectious hepatitis, an experimental animal was developed on the organism of the dogs - from 10 patients and control-out of 10 healthy. The applied treatment for infectious dogs' hepatitis was comprehensive, and included silence, calmness and diet therapy. In order to restore the functional status of the dogs' liver with hepatitis, the treatment regimen included 5\% glucose solution with 5\% solution of ascorbic acid in a dose, $40 \%$ solution of glutargin and $2 \%$ solution of riboxin for 5-10 days. Assigned vitamin preparation hepavicle and used symptomatic therapy. For the normalization of the function and regeneration of the liver after the action of adenovirus, as well as to reduce the negative effects of drugs having hepatotoxic action used hepato-lik. In order to assess the efficacy of the treatment, animals were examined clinically and blood samples were taken for the conduct of studies on the 10th and 30th day of treatment. The scheme of treatment for infectious dogs' hepatitis using hepatoprotector hepatolique has been used to improve the functional state of the liver, which was manifested in the restoration of the white-oxidative, pigmentary, anti-toxic function, improvement of detoxification function, the suppression of liver inflammation, and also contributed to the preservation and restoration of the structure of hepatocytes, normalization of ammonia levels in the dog's organism, accelerated the regeneration of the liver cells, and had little positive effect on erythrocytopoies and on the general condition of the orgnism in general.

Key words: dogs, infectious hepatitis, pathogenesis, treatment, hepato-lik.

\section{Патогенетичні аспекти лікування інфекційного гепатиту собак}

\author{
О.Є. Галатюк, Т.О. Романишина, А.Р. Лахман
}

Житомирський національний агроекологічний університет, м. Житомир, Украӥна

В статті показано механізми розвитку та динаміку змін при лікуванні інфекиійного гепатиту в собак. Згідно з повідомленнями лікарів ветеринарної медицини в клініках дрібних тварин м. Житомира у собак домінують такі інфекційні хвороби: парвовірусний ентерит, вірусний гепатит, парагрип собак, лептоспіроз, чума м'ясоїдних, трихофітія та харчові токсикоінфекиї. Одним із 
найбільи поширених захворювань у клінічній практиці виявився інфекійний гепатит, який став об'єктом наших досліджень. Вивчення різноманітних аспектів патології печінкової функиї при захворюваннях вірусної етіологї особливо актуальне в зв'язку з тим, що в силу виняткових компенсаторних потениій иього органу їх клінічний прояв часто з'являсться вже в стадії важких морфофункиіональних порушень, щзо не піддаються зворотному розвитку. Метою нашої роботи було вивчити вплив Адеполіги сапіпе - збудника інфекиійного гепатиту собак - на функціональний стан печінки, з'ясувати ефективність препарату гепатолік у складі комплексної інтенсивної терапії хворих собак. Об'єктом досліджень були хворі на інфекційний гепатит собаки. Головним діагностичним критерієм було застосування експрес-тестів, за допомогою яких був підтверджений попередній діагноз - інфекційний гепатит собак. Для дослідження ефективності застосованого лікування при інфекційному гепатиті на організм собак була

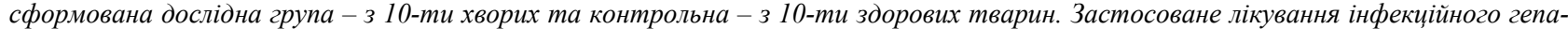
титу собак було комплексним і включало тишу, спокій та дієтотерапію. 3 метою відновлення функціонального стану печінки у собак, хворих на гепатит, у схему лікування включали 5\% розчин глюкози із 5\% розчином аскорбінової кислоти в дозі, 40\% розчином глутаргіну та 2\% розчином рибоксину впродовж 5-10 днів. Призначали вітамінний препарат гепавікел та застосовували симптоматичну терапію. Для нормалізації функиії і регенерації печінки після дії аденовірусу, а також, для зниження негативного впливу лікарських засобів, ичо мають гепатотоксичну дію, застосовували гепато-лік. Для оцінки ефективності проведеного лікування тварин клінічно обстежували і відбирали проби крові для проведення досліджень на 10 і на 30 -й день лікування. Використана нами схема терапї за інфекційного гепатиту собак із використанням гепатопротектору гепато-лік забезпечила поліпиення функціонального стану печінки, щзо проявлялось у відновленні білоксинтезувальної, пігментної, антитоксичної функції, поліпшенні дезінтоксикаційної функції, призупиненні запалення печінки, також сприяло збереженню та відновленню структури гепатоцитів, нормалізувало рівень аміаку в організмі собак, прискорювало регенерацію клітин печінки і мало позитивний вплив на еритроцитопоез і на загальний стан організму.

Ключові слова: собаки, інфекиійний гепатит, патогенез, лікування, гепато-лік.

\section{Ветуп}

Для забезпечення ветеринарного благополуччя i профілактики заразної та незаразної патології у дрібних тварин функціонують державні та приватні ветеринарні клініки. В даний час актуальним є вивчення епізоотичної ситуації щодо запобігання заразним хворобам у собак та удосконалення методів і способів ранньої діагностики, лікування, профілактики та заходів боротьби. Нозологічна структура хвороб собак у різних регіонах України різноманітна й залежить від природно-географічного розташування (Dmytrenko \& Mizin, 2014).

Згідно з повідомленнями лікарів ветеринарної медицини - в клініках дрібних тварин м. Житомира у собак домінують такі інфекційні хвороби: парвовірусний ентерит, вірусний гепатит, парагрип собак, лептоспіроз, чума м'ясоїдних, трихофітія та харчові токсикоінфекції. Висококонтагіозні вірусні захворювання проявляються характерним симптомокомплексом, за рахунок якого можлива постановка попереднього діагнозу до підтвердження лабораторними дослідженнями. Проблемою таких хвороб є виділення збудника в зовнішне середовище під час інкубаційного періоду, що $є$ особливо небезпечним під час виставок собак або сумісного вигулу (Bogdanos et al., 2012).

Одним із найбільш поширених захворювань у клінічній практиці виявився інфекійний гепатит, який став об’єктом наших досліджень. Гепатопатії є поширеною причиною захворюваності та смертності у собак. Ензоотія інфекційного гепатиту має сезонний характер, найчастіше спостерігається навесні та влітку (Dmytrenko \& Mizin, 2014). Спорадичні випадки захворювання реєструються у будь-яку пору року, що пов'язане в основному із загостренням латентного або хронічного перебігу хвороби. Основна причина більшості випадків собачого гепатиту маловідома, тому лікування, зазвичай $\epsilon$ паліативним, а власникам важко дати точні прогнозні відомості. Для Adenovirus canine (CAVs) клітинами-мішенями $\epsilon$ печінкові клітини, на що вказує експресія класу II мононуклеарної системи
(MHC) в гепатоцитах. Основна патогенетична дія вірусу, який вражає МНС гепатоцитів II класу, спрямована на виникнення аутосенсибілізації в організмі ураженої тварини, коли представлений антиген $\epsilon$ аутоантигеном гепатоцитарного походження (Longhi et al., 2007; Bogdanos et al., 2012). Білковий фрагмент інфекційного агента, представлений імунній системі, дуже нагадує частину самостійного білка. Як наслідок, активізована імунна система не тільки атакує білковий фрагмент інфекційного агента, а й і білковий фрагмент самостійного білка. Поки молекула класу II MHC та аутоантиген залишаються в цитоплазмі, гепатоцит безпечний від реакції імунної системи. Коли аутоантигенний комплекс досягає поверхні клітин, імунна система розпізнає комплекс і стає активованою (CD4 + Т-клітини), що і викликає аутоімунні реакції. Тобто, вплив вірусу не лише викликає запальні та дистрофічні процеси в організмі, а й негативно вливає на імунну систему хворої тварини, на що вказують зміни в регіональних лімфатичних вузлах: гіпертрофічні процеси внаслідок активізації імунної відповіді на патогенний чинник (Vergani et al., 2009; Dmytrenko \& Mizin, 2014; Speeti, 2014).

Вивчення різноманітних аспектів патології печінкової функції при захворюваннях вірусної етіології особливо актуальне в зв'язку з тим, що в силу виняткових компенсаторних потенцій цього органу їх клінічний прояв часто виявляється вже в стадії важких морфофункціональних порушень, що не піддаються зворотному розвитку (Kapoor et al., 2011; Vahrusheva, 2015).

Метою нашої роботи було вивчити вплив Adenovirus canine (CAVs) - збудника інфекційного гепатиту собак - на функціональний стан печінки, з'ясувати ефективність препарату гепато-лік у складі комплексної інтенсивної терапії хворих собак.

\section{Матеріал і методи досліджень}

Об'єктом досліджень були хворі на інфекційний гепатит собаки, пацієнти Навчально-науково- 
виробничої клініки ветеринарної медицини ЖНАЕУ. Під час виконання роботи нами використовувались амбулаторні журнали прийому хворих тварин, матеріали ветеринарної звітності. Умови утримання, годівлі та догляду за тваринами уточнювали за результатами опитування власників тварин.

Діагноз встановлювали за результатами клінічного обстеження тварин та результатами лабораторних досліджень. Головним діагностичним критерієм диференційної діагностики вірусних інфекційних хвороб у собак було застосування експрес-тестів (Hospitex Diagnostics, Italy) на аденовіро3, грип та чуму м'ясоїдних, за допомогою яких був підтверджений попередній діагноз інфекційний гепатит собак.

Для дослідження ефективності застосованого лікування при інфекційному гепатиті на організм собак була сформована дослідна 3 10-ти хворих та контрольна $з$ 10-ти здорових тварин. Групи собак були сформовані за принципом аналогів.

У всіх хворих тварин виявляли загальне пригнічення, анорексію, малорухливість, інколи блювання, зниження апетиту, слинотечу, проноси, спрагу, тьмяність та випадіння волосяного покриву, алопеції, сухість та зменшену еластичність шкіри, блідість та істеричність кон'юнктиви, видимих слизових оболонок та шкіри у хворих собак.

Від здорових та хворих тварин відбирали кров i визначали гематологічні показники за загальноприйнятими методами (Nimand \& Suter, 2008). Біохімічні дослідження сироватки крові (вміст загального білка, альбумінів, білірубіну АСТ, АЛТ) проводили за допомогою напівавтоматичного біохімічного аналізатоpa Rayto-1904C.

Для оцінки ефективності проведеного лікування тварин клінічно обстежували і відбирали проби крові для проведення досліджень на 10 і на 30-й день лікування.

Отримані результати досліджень проб крові собак дослідної та контрольної груп обробляли методом варіаційної статистики з використанням стандартного програмного пакета Staticus 5,0 для Windows 2010.

\section{Результати та їх обговорення}

Аналіз епізоотологічної ситуації щодо вірусного гепатиту собак показав, що хвороба регулярно реєструється в зоні обслуговування клінік дрібних тварин м. Житомира. Для даної хвороби відсутня виражена сезонність та відмічається пропорційне ураження тварин різних вікових груп, на відміну від чуми м'ясоїдних та парвовірусного ентериту. Динаміка прояву інфекційного гепатиту має тенденцію до зрос- тання за останні три роки. Так, у 2018 році захворіло 36 собак, що на 45\% більше, ніж у 2017 році (19 вип.), і на $33 \%$ більше, ніж у 2016 р (24 вип.).

Застосоване лікування інфекційного гепатиту собак було комплексним і включало тишу, спокій та дієтотерапію. 3 метою відновлення функціонального стану печінки у собак, хворих на гепатит, у схему лікування включали 5\% розчин глюкози в дозі 10 20 мл/кг, яку вводили повільно внутрішньовенно крапельно разом із 5\% розчином аскорбінової кислоти в дозі $2 \mathrm{~cm}^{3}$ на тварину, $40 \%$ розчином глутаргіну в дозі $0,05 \mathrm{~cm}^{3} /$ кг маси тіла та $2 \%$ розчином рибоксину в дозі $5 \mathrm{~cm}^{3}$ на тварину, впродовж 5-10 днів.

Для нормалізації функції і регенерації печінки після дії аденовірусу, а також для зниження негативного впливу лікарських засобів, що мають гепатотоксичну дію, застосовували гепато-лік, який вводили перорально, індивідуально, примусово за допомогою шприца-дозатора 3 рази на добу протягом місяця у дозі $3 \mathrm{~cm}^{3}$ на тварину.

Також призначали комплексний вітамінний препарат гепавікел. Його застосовували підшкірно в дозі $0,1 \mathrm{~cm}^{3}$ на 1 кг маси тіла, 1 раз на день - упродовж 10 днів. Для зняття больової реакції і спазмолітичний засіб призначали но-шпу в дозі $0,05-0,1 \mathrm{~cm}^{3}$ на кг маси тіла внутрішньом'язово 1 раз на добу. Для поліпшення моторики шлунково-кишкового тракту і запобігання блюванню, використовували $0,5 \%$ розчин метаклопраміду внутрішньом'язово в дозі 2 см$^{3} /$ тварину 12 рази на день. В перші дні для поліпшення діурезу застосовували $1 \%$ р-н фуросеміду в дозі $0,5-1 \mathrm{~cm}^{3} / \kappa \Gamma$ маси тіла 1 раз на день. Для запобігання розвитку гіпокаліємії і гіпомагніємії застосовували аспаркам в дозі по 25 мг/кг двічі на день.

При клінічному обстеженні за період лікування (10 діб) в групі хворих тварин відмічали поліпшення загального стану. В 5 тварин вгодованість була доброю та ще 4 тварини мали задовільну вгодованість. У дослідних тварин на 8-10 добу зникли алопеції, знизилось випадіння волосся, шкіра набула еластичності. У 70\% хворих тварин кон'юнктива набула рожевого кольору, проте у 3 собак ще спостерігалась анемічність, іктеричність шкіри у всіх тварин зникла. У хворих собак уже на 4-6 день лікування з'вився апетит. Після повного курсу лікування (30 діб) тварини дослідної групи були клінічно здоровими.

При дослідженні стану гемопоезу виявили, що вміст гемоглобіну в крові хворих на гепатит собак був достовірно $(\mathrm{P}<0,05)$ знижений i становив $148,7 \pm 10,70$ г/л, кількість еритроцитів була незначно підвищена 8,6 \pm 0,42 Т/л (табл. 1).

\section{Таблиця 1}

Морфологічні показники крові у собак на 10 та 30 добу лікування, $\mathrm{M} \pm \mathrm{m}$

\begin{tabular}{lcccc}
\hline \multicolumn{1}{c}{ Показники } & $\begin{array}{c}\text { Початок лікування } \\
(\mathrm{n}=10)\end{array}$ & $\begin{array}{c}10 \text { день лікування } \\
(\mathrm{n}=10)\end{array}$ & $\begin{array}{c}30 \text { день лікування } \\
(\mathrm{n}=10)\end{array}$ & $\begin{array}{c}\text { Клінічно здорові } \\
(\mathrm{n}=10)\end{array}$ \\
\hline Еритроцити, Т/л & $8,6 \pm 0,42$ & $7,03 \pm 0,7$ & $7,0 \pm 0,3$ & $6,9 \pm 0,2$ \\
Гемоглобін, Г/л & $148,7 \pm 10,70^{*}$ & $150,1 \pm 5,6$ & $165 \pm 4,5^{*}$ & $168,8 \pm 2,4$ \\
Лейкоцити, Г/л & $6,73 \pm 0,69$ & $7,52 \pm 0,7^{*}$ & $9,0 \pm 0,2$ & $8,98 \pm 0,15$ \\
\hline
\end{tabular}

Примітка: * - $\mathrm{P}<0,05$ порівняно з початком лікування 
Ймовірно, зменшення кількості гемоглобіну в крові хворих тварин зумовлено пригніченням фукції кістковго мозку, синтезу вітамінів групи В та інших органів гемопоезу. Встановлено, що розвиток клінічної картини гепатиту у собак спричиняе значні негативні зрушення в показниках еритроцитів. Структура еритроцитів зазнає значної деформації, в крові зменшується кількість дискоцитів і нормоцитів. Крім того, з'явилися ехіноцити, шизоцити, тільця Жоллі, велика кількість дрібних еритроцитарних агрегатів (Vahrusheva, 2015; Rodionov et al., 2018). Все це вказуе на те, що інфекційний гепатит зумовлює розвиток комплексного відновлення еритрону. Існує стійка складність мікроциркуляції, погіршення загального стану та значне зниження опору i, отже, утруднення перфузії капілярів та обміну речовин по всьому організмy (Rodionov et al., 2018).

Після застосованого лікування кількість еритроцитів у хворих собак зменшилось з $8,6 \pm 0,42$ Т/л до
7,03 $\pm 0,7$ на 10-й день від початку лікувальних заходів. Вміст гемоглобіну під час терапії собак вірогідно $(\mathrm{P}<0,05)$ зріс у порівняно з початком лікування.

Такі зміни у кров'яному руслі, на нашу думку, відбулись за рахунок впливу медикаментозного лікування на стимулювання синтезу органів гемопоезу, зокрема кісткового мозку. Збільшилась кількість нормоцитів і дискоцитів, а ехіноцити, шизоцити, та тільця Жюллі у крові не реєструвалися.

У лейкограмі хворих тварин встановлено регенеративний зсув нейтрофілів, а саме зростання кількості паличкоядерних нейтрофілів до $8,8 \pm 1,18 \%$, що майже у 3 рази більше, ніж у клінічно здорових. У хворих виявили тенденцію до збільшення лімфоцитів $(45,1 \pm$ $1,24 \%)$ порівняно з клінічно здоровими $(35,4 \pm 1,75 \%)$, що $є$ характерною рисою інфекцій вірусної етіології (табл. 2).

\section{Таблиця 2}

Лейкограма собак хворих на інфекційний гепатит на 10 -ту та 30-ту добу лікування, $\mathrm{M} \pm \mathrm{m}$

\begin{tabular}{|c|c|c|c|c|c|c|}
\hline \multicolumn{3}{|c|}{ Показники, \% } & $\begin{array}{l}\text { Початок } \\
\text { лікування }\end{array}$ & $\begin{array}{l}10 \text { день } \\
\text { лікування }\end{array}$ & $\begin{array}{l}30 \text { день } \\
\text { лікування }\end{array}$ & Клінічно \\
\hline \multirow{6}{*}{ 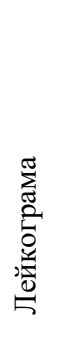 } & Базофіли & & - & - & - & - \\
\hline & Еозинофіли & & $6,0 \pm 1,63$ & $6,0 \pm 1,5$ & $5,9 \pm 0,9$ & $6,8 \pm 0,8$ \\
\hline & \multirow{4}{*}{ Нейтрофіли } & Мієлоцити & - & - & - & - \\
\hline & & Юні & - & - & - & - \\
\hline & & Паличкоядерні & $8,8 \pm 1,18$ & $6,8 \pm 1,2^{*}$ & $4,0 \pm 1,5^{* *}$ & $3,5 \pm 2,5$ \\
\hline & & Сегментоядерні & $34,5 \pm 3,5$ & $39,5 \pm 2,9$ & $48,7 \pm 3,2^{* *}$ & $49,8 \pm 0,5$ \\
\hline \multicolumn{3}{|c|}{ Лімфоцити } & $45,1 \pm 1,24$ & $42,5 \pm 1,3$ & $37,1 \pm 1,1^{* *}$ & $35,4 \pm 1,75$ \\
\hline \multicolumn{3}{|c|}{ Моноцити } & $5,6 \pm 1,33$ & $5,2 \pm 1,4^{*}$ & $4,3 \pm 0,5^{* *}$ & $4,5 \pm 0,5$ \\
\hline
\end{tabular}

Примітка: * - $\mathrm{P}<0,05 ; * *-\mathrm{P}<0,01$ порівняно з початком лікування

Такі зрушення в лейкограмі характерні для дегенеративних процесів у органах, що є логічно обумовленими некротичними змінами в печінці, а також свідчить про підвищену діяльность кісткового мозку, який, як відомо, $є$ органом кровотворення і намагається компенсувати погіршення функціонального стану печінки (Dmytrenko \& Mizin, 2014).

Інфекційний гепатит собак характеризується розвитком некрозу в печінці та супутнім запаленням. Некроз зазвичай пов'язаний з колапсом ретикулярної структури. Запальний інфільтрат при такому ураженні печінки ймовірно складається 3 “круглих" клітин i нейтрофілів, a також також кероїд-заповнених макрофагів, що називаються “калібрувальними клітинами" (Cherkashina et al., 2016).

На 10-ту добу лікування собак в їх лейкограмі було виявлено відсутність юних нейтрофілів, зменшення кількості паличкоядерних нейтрофілів, встановлено збільшення кількості сегментоядерних нейтрофілів, а кількість лімфоцитів поступово знижувалась (табл. 2). На 30-ту добу лікування виявляли наближення усіх показників крові до показників тварин контрольної групи.

При біохімічному дослідженні крові собак дослідної групи спостерігали гіпопротеїнемію, гіпоальбумінемію, що свідчить про порушення білкового обміну, гіпербілірубінемію, що вказує на порушення функції пігментного обміну та антитоксичної функції, гіперферментемію, у 6,3 разу збільшився середній показник активності аспарагінової трансферази порівняно 3 клінічно здоровими тваринами, активність аланінової трансамінази теж збільшилась у 12 разів і становила $475 \pm 71,5$ Од/л (табл. 3). Збільшення активності даних трансаміназ свідчить про синдром цитолізу гепатоцитів, гострий запальний процес у печінці, викликаний розмноженням аденовірусу в клітинах печінки (Rakich et al., 1986; Sawhney \& Visvanathan, 2011).

При гепатиті може виникати лихоманка в результаті дії пірогенів з некротичної тканини та від зменшення видалення ендотоксинів, бактеріальних 
патогеннів та залишків зруйнованих вірусом гепатоцитів 3 портальної крові (Dmytrenko \& Mizin, 2014). Інтенсивний некроз печінкової клітини називають фульмінантним гепатитом (миттєвим), що може викликати розвиток печінкової енцефалопатії, ДВЗ синдрому (порушення згортання крові), жовтяниці та гіпоглікемії. Ця важка форма швидко прогресує до коми та смерті (Morozenko \& Tymoshenko, 2012). Продовженням гострого інфекційного гепатиту може бути хронічний процес. Поступово прогресуючий некроз клітин печінки призводить до постійної гіперферментемії всіх ферментів печінки (АСТ, АЛТ) та жовчних кислот.
Функція печінки зменшується за рахунок втрати функціональної тканини та зменшення портального кровотоку. Перетворення аміаку залишається адекватним до розвитку портосистемних колатералей. Гіпоальбумінемія та портальна гіпертензія можуть викликати асцит. У собак з діагнозом “гепатит", спостерігається підвищення концентрації продуктів ПОЛ, що характеризує посилення процесів перекисного i вільноорадикального окислення. Концентрація антиоксидантів знижується, що вказує на зниження антиоксидантного захисту організму (Kearns, 2009; Lai \& Liaw, 2010; Speeti, 2014).

Таблиця 3

Біохімічні показники крові на 10 і 30 добу лікування інфекційного гепатиту, $\mathrm{M} \pm \mathrm{m}$

\begin{tabular}{|c|c|c|c|c|}
\hline Показники & $\begin{array}{c}\text { Початок } \\
\text { лікування, } \\
(\mathrm{n}=10)\end{array}$ & $\begin{array}{c}10 \text { день } \\
\text { лікування } \\
(\mathrm{n}=10)\end{array}$ & $\begin{array}{c}30 \text { день } \\
\text { лікування } \\
(n=10)\end{array}$ & $\begin{array}{c}\text { Клінічно } \\
\text { здорові } \\
(\mathrm{n}=10) \\
\end{array}$ \\
\hline Загальний білок, г/л & $61,51 \pm 6,84$ & $69,07 \pm 3,6$ & $71,0 \pm 2,9$ & $73,6 \pm 1,3$ \\
\hline Альбуміни, \% & $28,05 \pm 1,13$ & $43,1 \pm 2,3 * *$ & $46,6 \pm 2,4^{* *}$ & $52,5 \pm 0,4$ \\
\hline Загальний білірубін, мкмоль/л & $8,23 \pm 1,11$ & $4,5 \pm 0,7 * *$ & $3,2 \pm 0,9 * *$ & $3,4 \pm 1,4$ \\
\hline АСТ, Од/л & $109,55 \pm 17,02$ & $54,75 \pm 16,5 * *$ & $32,5 \pm 14,9 * *$ & $17,5 \pm 2,4$ \\
\hline АЛТ, Од/л & $475 \pm 71,5$ & $110,5 \pm 13,6^{* *}$ & $59,8 \pm 10,8 * *$ & $39,3 \pm 1,9$ \\
\hline
\end{tabular}

Примітки: **- $\mathrm{P}<0,001$ порівняно з початком лікування

Так, на 10-у добу лікувальних заходів вміст загального білка був на рівні 69,07 $\pm 3,6$ г/л, тобто спостерігалось його збільшення. Аналогічна тенденція реєструвалась і з рівнем альбумінів. Таке зростання вмісту загального білка і альбумінів в сироватці крові свідчить про підвищення білоксинтезувальної функції печінки, що стало можливим у зв'язку з відновленням структури і функції гепатоцитів внаслідок дії й гепатопротектора гепато-ліку.

В процесі лікування достовірно (Р < 0,001) зменшувалась активність аспарагінової трансферази у сироватці крові. Так, до лікування середній показник активності АСТ становив 109,55 \pm 17,02 Од/л, на 10ту добу лікувальних заходів середній показник зменшився у 2 рази а на 30-ту добу - до 32,5 \pm 14,9 Од/л. Середнє значення активності аланінової трансферази також достовірно (P < 0,001) зменшувалось на 10 добу лікування, а на 30-ту добу лікування становила $59,8 \pm 10,8$ Од/л, що є меншим ніж на початку лікування $475 \pm 71,5$ Од/л, але всеодно вищим, ніж у клінічно здорових тварин, що пояснюємо часом, потрібним для відновлення структури гепатоцитів.

Стабілізація рівня трансфераз в крові, на нашу думку, свідчить про можливу активацію в печінці регенераторних процесів внаслідок впливу гепатопротектора ГЕПАТО-ЛІК, що використовувався для лікування хворих собак. Препарат містить специфічні нутріцевтичні компоненти, які мають мембраностабілізуючі, гепатопротекторні, антиоксидантні властивості. Комплекс складових біологічно активних речовин поліпшує функціональний стан печінки і іiі дезінтоксикаційну функцію, сприяє збереженню та відновленню структури гепатоцитів, нормалізує рівень аміаку в організмі тварин, прискорює регенерацію клітин пе- чінки. При поліпшенні функціонального стану печінки нормалізується робота всіх систем організму. При захворюванні собак інфекційним гепатитом не так просто досягти повного одужання протягом місяця. Лікування інфекційного гепатиту здебільшого визначається підтримуючою терапією. Необхідно регулярно проводити дослідження крові та корегування медикаментів. Застосування гапето-ліку у традиційній схемі лікування інфекційного гепатиту собак дало добрий лікувальний ефект, що підтверджено дослідженням біохімічних показників крові на 10 та 30 добу лікування.

Відомо, що хворобу найкраще профілактувати насамперед за допомогою вакцинації. Метою вакцинації $\epsilon$ індукування пам'яті в Т і /або В лімфоцитів шляхом ін'єкції препаратів авірулентного антигену (Longhi et al., 2007; Lai \& Liaw, 2010; Jin et al., 2019). Таким чином, у разі фактичної інфекції інфекційний агент зустрічається 3 активованою імунною системою i захворювання не розвивається. Коли ж виникає захворювання, то потрібно застосовувати комплексне лікування із застосуванням нового препарату - гепато-ліку.

\section{Висновки}

1. У собак, хворих на інфекційний гепатит, уражається печінка, серце, травна та сечовидільна системи, пригнічується еритро- та лейкопоез. Зазначені зміни підвищують актуальність вивчення патогенезу, розробки методів ранньої діагностики і корекції функціонального стану печінки як основного органу стабілізації гомеостазу організму в нормі і при даній патології. 
2. На 30-ту добу лікування у хворих на інфекційний гепатит собак морфологічні показники крові були наближені до показників здорових тварин. За цей період відновились процеси гемопоезу в організмі та білоксинтизувальна_функція печінки, поступово нормалізувався вміст білірубіну і виникала тенденція до зниження активності трансаміназ, однак середній показник їх вмісту в сироватці крові ще перевищував норму - АЛТ (59,8 $\pm 10,8$ Од/л), АСТ (32,5 \pm 14,9 Од/л).

3. Обрана схема лікування собак, хворих на інфекційний гепатит, з включенням в неї гепато-ліку є ефективною та сприяє відновленню структури і функції життєво важливих органів тварин, що в подальшому поліпшує функціонування організму загалом.

Перспективи подальших досліджень. 1. Удосконалити схему застосування наявних вакцин проти інфекційного гепатиту собак, які містять антигени двох типів вірусу, для створення стійкого імунітету. Для вакцин, що вводяться підшкірно (s.c.) або внутрішньом'язово (i.m.), ретельно вибирати ділянку вакцинації, оскільки через неоднорідний розподіл лімфоцитів в організмі шанси, що антигени, введені в різних місцях, різні й імунні реакції, що провокуються антигенами, також можуть бути різними.

2. Досліджувати ефективність підтримуючої та відновлюючої терапії за інфекційного гепатиту собак 3 включенням економічно вигідних препаратів комплексного складу, які сприяють швидкому одужанню тварини.

\section{References}

Bogdanos, D.P., Smyk, D.S., Rigopoulou, E. I., et al. (2012). Twin studies in autoimmune disease: genetics, gender and environment. J. Autoimmun, 38(2-3), 156-J169. doi: 10.1016/j.jaut.2011.11.003.

Cherkashina, M.A., Gorjacheva, M.A., \& Dorofeeva, V.P. (2016). Patologija pecheni u sobak. Nauchnyj al'manah, 12(2), 382-385. https://elibrary.ru/ item.asp?id $=28387708$ (in Russian).

Dmytrenko, N.I., \& Mizin, A.V. (2014). Osoblyvosti kliniko-morfolohichnoho proiavu virusnoho hepatytu sobak. Visnyk Sumskoho natsionalnoho ahrarnoho universytetu: Veterynarna medytsyna, 1(34), 104-106. http://nbuv.gov.ua/UJRN/Vsna_vet_2014_1_31 (in Ukrainian).

Jin, H., Xu, Y., Shi, F., \& Hu, S. (2019). Vaccination at different anatomic sites induces different levels of the immune responses. Research in veterinary science, 122, 50-55. doi: 10.1016/j.rvsc.2018.11.005.

Kapoor, A., Simmonds, P., Gerold, G., et al. (2011). Characterization of a canine homolog of hepatitis $\mathrm{C}$ virus. Proc Natl Acad Sci USA. 108, 11608-11613. doi: 10.1073/pnas.1101794108.
Kearns, S. (2009). Infectious hepatopathies in dogs and cats. Top Companion Anim Med., 24(4), 189-198. doi: 10.1053/j.tcam.2009.06.004.

Lai, M., \& Liaw, Y.F. (2010). Chronic hepatitis B: past, present, and future. Clin Liver Dis., 14(3), 531-546. doi: 10.1016/j.cld.2010.05.003.

Longhi, M.S., Hussain, M.J., Bogdanos, D.P., et al. (2007). Cytochrome P450IID6-specific CD8 T cell immune responses mirror disease activity in autoimmune hepatitis type 2. Hepatology. 46(2), 472-484. doi: 10.1002/hep.21658.

Marcellin, P. (2009). Hepatitis B and hepatitis C in 2009. Liver Int., 29(1), 1-8. doi: 10.1111/j.14783231.2008.01947.x.

Morozenko, D.V., \& Tymoshenko, O.P. (2012). Biokhimichni pokaznyky stanu spoluchnoi tkanyny u patohenezi, diahnostytsi ta kontroli efektyvnosti likuvannia hepatopatii sobak. Biolohiia tvaryn, 14(1-2), 411-419 http://nbuv.gov.ua/UJRN/bitv_2012_14_1-2_67 (in Ukrainian).

Nimand, H.G., \& Suter, P.F. (2008). Prakticheskoe rukovodstvo dlja veterinarnyh vrachej (organizacija veterinarnoj kliniki, obsledovanie, diagnostika zabolevanij, lechenie). M.: Akvarium-print (in Russian).

Poldervaart, J.H., Favier, R.P., Penning, L.C., et al. (2009). Primary hepatitis in dogs: a retrospective review (2002-2006). J Vet Intern Med. 23(1), 72-80. doi: 10.1111/j.1939-1676.2008.0215.x.

Rakich, P.M., Prasse, K.W., Lukert, P.D. et al. (1986). Immunohistochemical detection of canine adenovirus in paraffin sections of liver. Vet Pathol. 23(4), 478484. doi: 10.1177/030098588602300419.

Rodionov, V.D., Vatnikov, Ju.A., \& Vilkovyskij, I.F. (2018). Diagnostika jeritrocitarnyh narushenij pri ostrom gepatite u sobak. Teoreticheskie i prikladnye problemy agropromyshlennogo kompleksa, 2(35), 2227 (in Russian).

Sawhney, R., \& Visvanathan, K. (2011). Polymorphisms of toll-like receptors and their pathways in viral hepatitis. Antivir Ther, 16, 443-458. doi: 10.3851/IMP1820.

Speeti, M. (2014). Doberman hepatitis: comparison of subclinical and clinical stages and evaluation of etiopathogenesis of the disease. Helsinki: Department of Bacteriology and Immunology Haartman Institute, University of Helsinki.

Vahrusheva, T.I. (2015). Patomorfologicheskie izmenenija pri infekcionnom gepatite u sobak. Vestnik Krasnojarskogo gosudarstvennogo agrarnogo universiteta, 2, 33-38. https://cyberleninka.ru/article/n/ patomorfologicheskie-izmeneniya-pri-infektsionnomgepatite-u-sobak (in Russian).

Vergani, D., Longhi, M.S., Bogdanos, D.P. et al. (2009). Autoimmune hepatitis. Semin Immunopathol. 31(3), 421-435. doi: 10.1007/s00281-009-0170-7. 